\title{
SINKHOLE DEVELOPMENT RESULTING FROM GROUND-WATER WITHDRAWAL IN THE TAMPA AREA, FLORIDA
}

U.S. GEOLOGICAL SURVEY

WATER-RESOURCES INVESTIGATIONS 81-50

Prepared in cooperation with the

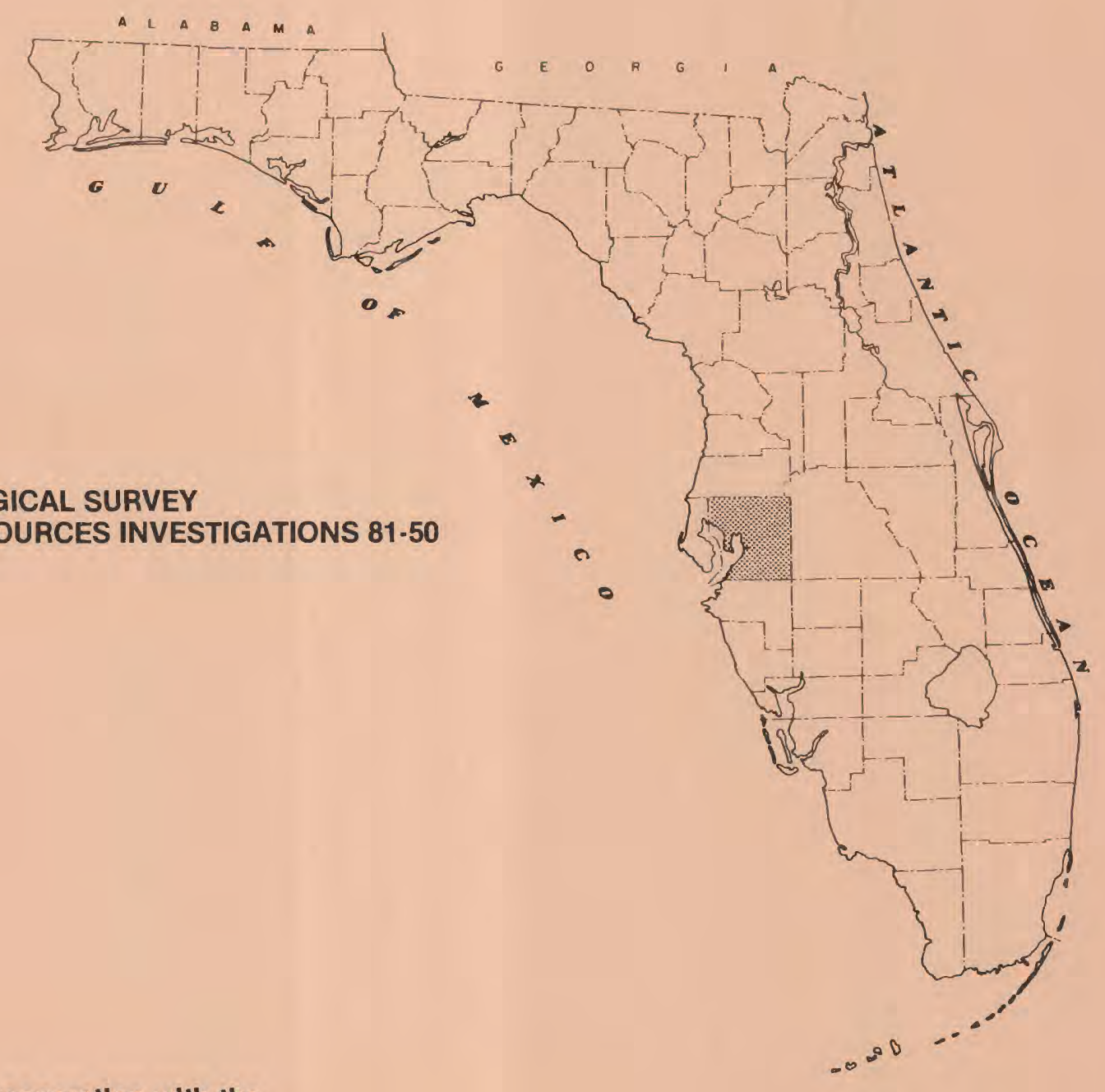

SOUTHWEST FLORIDA WATER MANAGEMENT DISTRICT 


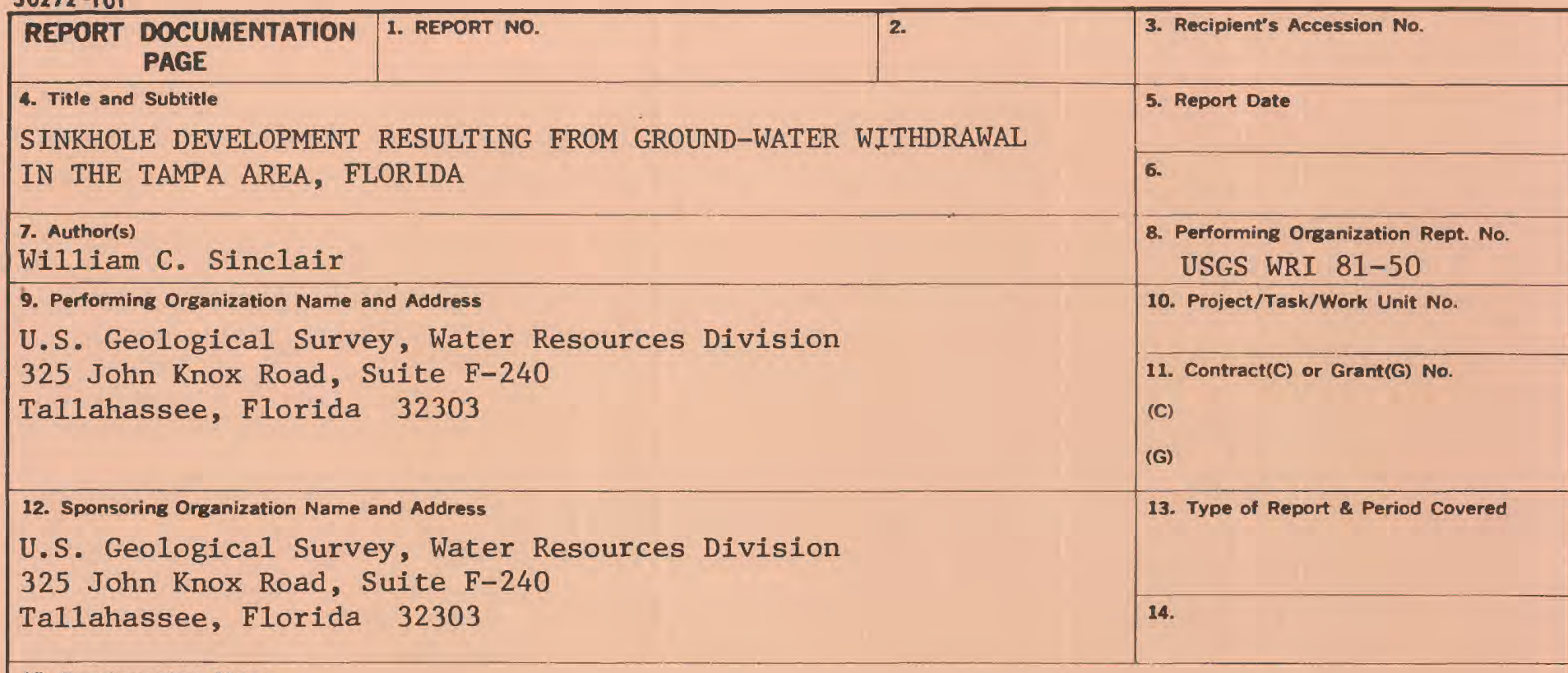

15. Supplementary Notes

Prepared in cooperation with the Southwest Florida Water Management District

16. Abstract (Limit: 200 words) The area of municipal well fields on the Gulf Coastal Plain north of Tampa is densely pitted with natural sinkholes and sinkhole lakes that have resulted from collapse of surficial sand and clay into solution cavities in the underlying carbonate rocks of the Floridan aquifer. Although solution of the underlying rocks is the ultimate cause of sinkholes, some have been induced by abrupt changes in ground-water levels caused by pumping. Declines in water levels cause loss of support to the bedrock roofs over cavities and to surficial material overlying openings in the top of bedrock.

The volume of calcium, magnesium, and carbonate (the constituents of limestone and dolomite) in solution in the water withdrawn from four well fields near Tampa totaled about 240,000 cubic feet in 1978. Most induced solution takes place at the limestone surface however, and the area of induced recharge is so extensive that the effect of induced limestone solution on sinkhole development is negligible.

Alinement of established sinkholes along joint patterns in the bedrock suggests that a well located along these lineations might have direct hydraulic connection with a zone of incipient sinkholes. Therefore, installation of large-capacity wells along such lineations would increase the probability of sinkhole development.

Although sinkholes generally occur abruptly in the study area, local changes such as vegetative stress, ponding of rainfall, misalinement of structures, and turbidity in well water are all indications that precollapse subsidence may be in progress.

17. Document Analysis a. Descriptors

*Karst, Sinks, Subsidence, Pumping, Florida, Carbonate rocks

b. Identifiers/Open-Ended Terms

*Sinkhole collapse, Limestone solution, Subsurface erosion

c. COSATI Field/Group

18. Availability Statement

No restriction on distribution

19. Security Class (This Report) UNCLASSIFIED

20. Security Class (This Page) UNCLASS IF IED
21. No. of Pages 24

22. Price 
SINKHOLE DEVELOPMENT RESULTING FROM GROUND-WATER

WITHDRAWAL IN THE TAMPA AREA, FLORIDA

By William C. Sinclair

U.S. GEOLOGICAL SURVEY

Water-Resources Investigations $81-50$

Prepared in cooperation with the

SOUTHWEST FLORIDA WATER MANAGEMENT DISTRICT 


\section{UNITED STATES DEPARTMENT OF THE INTERIOR}

JAMES G. WATT, Secretary

GEOLOGICAL SURVEY

Doyle G. Frederick, Acting Director

For additional information write to:

U.S. Geological Survey

325 John Knox Road, Suite F-240

Tallahassee, Florida 32303 
Abstract - - 1

Introduction -

Hydrogeologic setting -_-_- 3

Mechanism of sinkhole collapse -

Effects of pumpage on limestone solution

Sinkhole collapse induced by pumpage

Precursors of sinkhole collapse - 17

Conclusions -

References -

\section{ILLUSTRATIONS}

Figure 1. Map showing location of study area

2. Photograph showing cypress head, typical of many on the Gulf Coastal Lowlands north of Tampa

3. Section showing mechanism of sinkhole collapse - 10

4. Photograph showing sinkhole that developed in the shore of Simmons Lake, Section 21 well field, in the summer of 1971 -- 12

5. Graph showing pumpage at Section 21 well field and water-level fluctuations in shallow and deep observation wells _-____- 14

6. Map of Section 21 well-field area 16

TABLE 
Factors for converting inch-pound units to International System (SI) units and abbreviation of units

\section{Mu1tiply}

inch

foot

mile

square mile $\left(\mathrm{mi}^{2}\right)$

cubic foot $\left(\mathrm{ft}^{3}\right)$

million gallons per day

(Mgal/d)

pound (1b)

ton
By

25.4

0.3048

1.609

2.59

0.02832

0.04381

0.4536

0.9072
To obtain

millimeter (mm)

meter ( $m$ )

kilometer $(\mathrm{km})$

square kilometȩr $\left(\mathrm{km}^{2}\right)$

cubic meter $\left(\mathrm{m}^{3}\right)$

cubiç meter per second $\left(\mathrm{m}^{3} / \mathrm{s}\right)$

kilogram (kg)

megagram (Mg)

National Geodetic Vertical Datum of 1929 (NGVD of 1929).--A geodetic datum derived from a general adjustment of the first-order level nets of both the United States and Canada, formerly called "mean sea level." NGVD of 1929 is referred to as sea level in this report. 


\title{
SINKHOLE DEVELOFMENT RESULTING FROM GROUND-WATER
}

\author{
WITHDRAWAL IN THE TAMPA AREA, FLORIDA
}

By William C. Sinclair

ABSTRACT

The area of municipal well fields north of Tampa is densely pitted with natural sinkholes and sinkhole lakes that have resulted from collapses of surficial sand and clay into solution cavities in the underlying carbonate rocks of the Floridan aquifer. Although solution of the underlying rocks is the ultimate cause of sinkholes, some have been induced by abrupt changes in groundwater levels caused by pumping. Declines in water levels cause loss of support to the bedrock roofs over cavities and to surficial material overlying openings in the top of bedrock. Alternate swelling-shrinking and support-withdrawal caused by seasonal fluctuations in water level tend to disrupt the cohesiveness of unconsolidated surficial material and promote collapse.

The volume of calcium, magnesium, and carbonate (the constituents of limestone and dolomite) in solution in the water withdrawn from four well fields near Tampa totaled about 240,000 cubic feet in 1978. Most induced solution takes place at the limestone surface however, and the area of induced recharge is so extensive that the effect of induced limestone solution on sinkhole development is negligible.

Alinement of established sinkholes along joint patterns in the bedrock suggests that a well along these lineations might have direct hydraulic connection with a zone of incipient sinkholes. Therefore, pumping of large-capacity wells along such lineations would increase the probability of sinkhole development.

Although sinkholes generally form abruptly in the study area, local changes such as vegetative stress, ponding of rainfall, misalinement of structures, and turbidity in well water are all indications that precollapse subsidence may be taking place.

\section{INTRODUCTION}

The limestone and dolomite that underlie the Florida peninsula to depths of several thousand feet are susceptible to chemical solution by acidic water that percolates through the soil and surficial sand and clay as natural recharge. Solution of carbonate rocks by ground water moving through them is the primary natural factor now altering the land surface of Florida. The purpose of this study is to define causes of sinkhole development in an area north of Tampa (fig. 1), particularly the relation of geology, hydrology, and hydrologic changes to the type and severity of subsidence or collapse. 


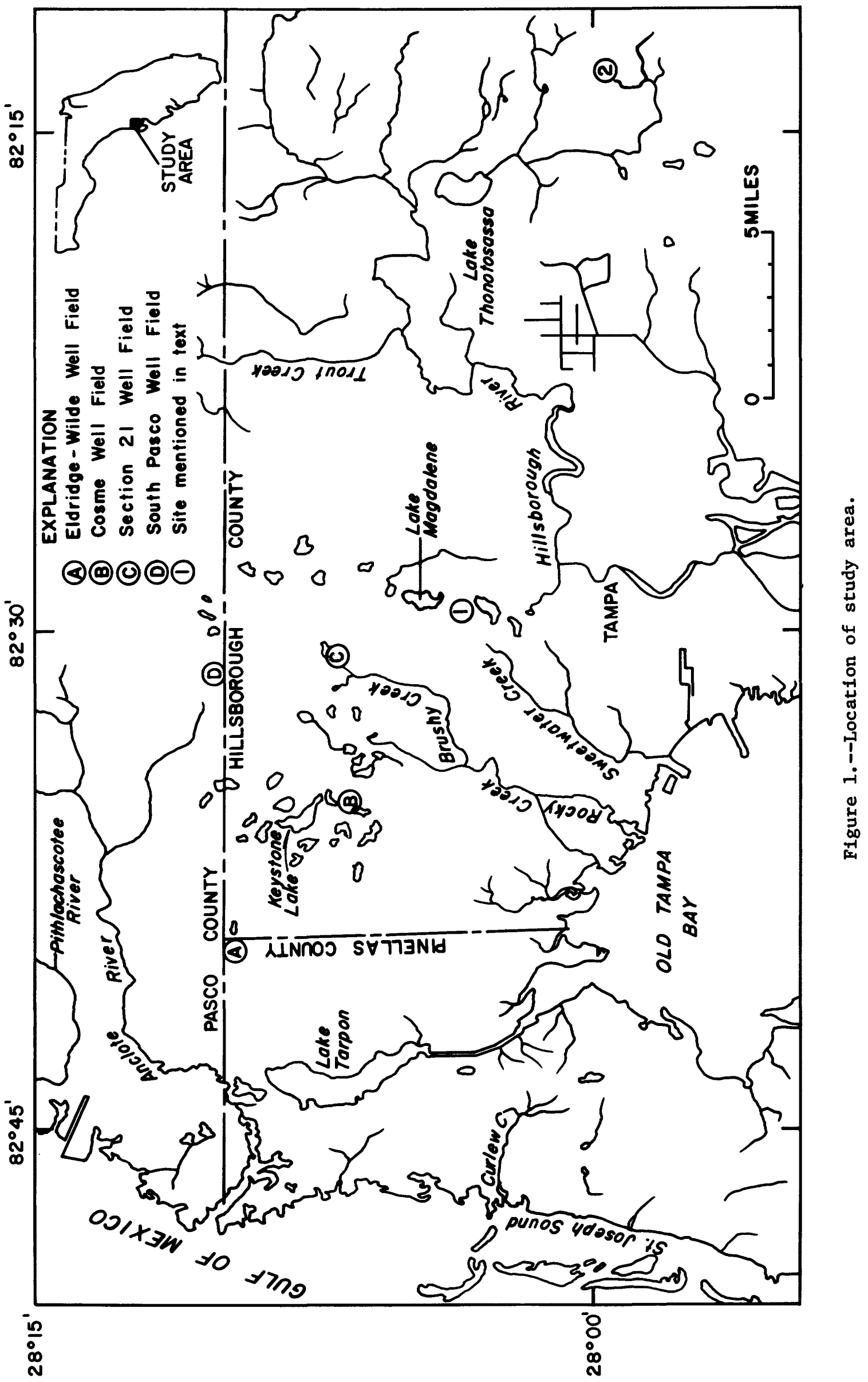


Ground-water pumpage in the study area, which contains four municipal well fields, has increased since the early 1930 's to an average $62 \mathrm{Mgal} / \mathrm{d}$ in 1978. Resultant drawdown of water levels in the artesian and surficial aquifers and modification of natural ground-water flow have affected the natural hydrologic regimen.

Some of the effects of pumpage have been to accelerate solution of limestone by increasing circulation of ground water. More importantly, however, drawdown of ground-water levels due to pumping may precipitate collapse or subsidence at localities where solution cavities are already present.

\section{HYDROGEOLOGIC SETTING}

Formations of limestone and dolomite and the unconsolidated sand and clay deposits that overlie them in the study area are described in table 1. Deposition of each limestone formation was followed by a period of emergence, erosion, and solution that resulted in development of surface irregularities and solution cavities. Thus, formations described in table 1 are separated by erosional unconformities. In addition to periods of erosion noted in table 1 , the occurrence of conglomerate in the Miocene Tampa Limestone and lignite and carbonaceous plant remains in the underlying Eocene Avon Park Limestone suggests periods of intraformational erosion that also might have contributed to development of solution cavities. The periods of erosion and solution resulted in an irregular formation surface that is responsible, in part, for the variation in thickness noted for each formation.

The uppermost consolidated rock, defined as bedrock in this report, is the Tampa Limestone. A large amount of sand and clay is disseminated throughout the limestone, and the dense, plastic clay that nearly everywhere overlies the limestone is a residuum of insoluble minerals concentrated by solution of the limestone. The clay has contorted bedding planes that are probably due to subsidence that took place as the limestone weathered. Concentrations of clay at the limestone surface indicate that most solution activity occurred at that surface. The residual clay is unconformably overlain by relatively flat-lying sand and clay laminae that grade upward into clean, well-sorted, fine sand at the land surface.

The water table in the surficial sand aquifer generally lies within a few feet of the land surface throughout the area. Water in the limestone Floridan aquifer is under artesian pressure and will rise in tightly cased wells to a level above the confining clay layer. The potentiometric surface of the Floridan aquifer generally stands 10 to 20 feet below the water table in the surficial aquifer. Downward leakage of water from the surficial aquifer to the Floridan, though retarded by the intervening layers of clay and sandy clay, is an important factor in local recharge to the Floridan aquifer. Movement of water from the surficial to the Floridan aquifer is greatly accelerated where the clay is absent or has been breached by sinkhole collapse or subsidence.

Numerous sma11, circular cypress swamps that dot the landscape are a characteristic feature of the study area. Locally called cypress heads because of their characteristic dome shape (fig. 2), these swamps occupy shallow sinkholes. 
Table 1.--Hydrogeologic units

\begin{tabular}{|c|c|c|}
\hline $\begin{array}{c}\text { Name of } \\
\text { unit }\end{array}$ & Description & Remarks \\
\hline \multirow[t]{2}{*}{$\begin{array}{l}\text { Surficial } \\
\text { sand }\end{array}$} & $\begin{array}{l}\text { The uppermost deposit underlying most of area of } \\
\text { figure } 1 \text { is a clean, well-sorted, fine to very } \\
\text { fine quartz sand containing clay at depth. The } \\
\text { sand has no apparent bedding and is noncohesive } \\
\text { except for a zone of cementation that occurs at } \\
\text { places near the surface. The sand is commonly } \\
\text { white to light tan or buff near the surface } \\
\text { where it often contains a mixture of organic } \\
\text { matter and silt. } \\
\text { Thickness } 0-35 \text { feet } 1 /\end{array}$ & $\begin{array}{l}\text { Modified from } \\
\text { Sinclair, } \\
\text { 1974, p. 10- }\end{array}$ \\
\hline & $\begin{array}{l}\text { The clay content of the massive sand unit seems } \\
\text { to increase gradually with depth. This clay } \\
\text { may have been reworked by wave action on the } \\
\text { underlying laminated sand and clay unit, thus } \\
\text { obscuring the contact. It is also possible } \\
\text { that the sand may be a near-shore facies of } \\
\text { the underlying unit. }\end{array}$ & \\
\hline $\begin{array}{l}\text { Sand and } \\
\text { clay }\end{array}$ & $\begin{array}{l}\text { A sequence of sand and clay layers lies uncon- } \\
\text { formably on the eroded surface of the weather- } \\
\text { ed clay residuum or the limestone where the } \\
\text { clay is absent. The mottles and crenulations, } \\
\text { which are common in the dense clay, are absent } \\
\text { in the laminated sand and clay. Stratifica- } \\
\text { tion in this unit is apparently undisturbed, } \\
\text { indicating that deposition occurred after that } \\
\text { period of weathering of the Tampa Limestone } \\
\text { represented by the dense clay. } \\
\text { Thickness } 0-200 \text { feet- }\end{array}$ & Do. \\
\hline
\end{tabular}

\section{PERIOD OF EROSION}

Clay

A dense, plastic clay overlies the Tampa Limestone throughout most of the area and is often calcareous and interbedded with thin layers of limestone near the base. The clay is generally green or greenish-gray, is streaked or mottled with gray and black, and contains sand. Carr and Alverson (1959, p. 52-53, fig. 14) have shown, with sand-clay ratios of the clay and unweathered limestone, that the clay is a residuum of the underlying Tampa Limestone. They postulate 5 to 10 feet of original limestone for each foot of residual clay. Thickness $0-20+$ feet $1 /$

Do. 
Table 1.--Hydrogeologic units--Continued

\begin{tabular}{|c|c|c|}
\hline $\begin{array}{l}\text { Name of } \\
\text { unit }\end{array}$ & Description & Remarks \\
\hline \multicolumn{3}{|c|}{ PERIOD OF EROSION } \\
\hline $\begin{array}{l}\text { Tampa } \\
\text { Limestone } \\
\text { (Miocene) }\end{array}$ & $\begin{array}{l}\text { Limestone typical of the Tampa is white to light } \\
\text { yellow, soft, moderately sandy and clayey, } \\
\text { finely granular, and locally fossiliferous. In } \\
\text { places, calcareous fossil remains constitute as } \\
\text { much as } 90 \text { percent of the rock. Many fossil } \\
\text { molds give this type of rock a high porosity. } \\
\text { Also present in the formation are lenses of } \\
\text { limestone conglomerate, green and gray clayey } \\
\text { sand, sandy clay, and clay-pebble conglomerate, } \\
\text { all more or less calcareous, except where they } \\
\text { have been deeply weathered. Chert is common, } \\
\text { both as surficial crusts and throughout the } \\
\text { formation, as platy fragments. } \\
\text { Thickness 50-100 feet } 1 /\end{array}$ & $\begin{array}{l}\text { Modified from } \\
\text { Carr and } \\
\text { Alverson, } \\
1959 \text {, p. } 8 \text {, } \\
10 \text {, and } 21 \text {. }\end{array}$ \\
\hline \multicolumn{3}{|c|}{ PERIOD OF EROSION } \\
\hline $\begin{array}{l}\text { Suwannee } \\
\text { Limestone } \\
\text { (Oligocene) }\end{array}$ & $\begin{array}{l}\text { The Suwannee is a pure, massive, homogeneous, } \\
\text { white to light-tan limestone that is fairly } \\
\text { soft and sometimes granular in appearance. It } \\
\text { contains only a small percentage of very fine } \\
\text { grained quartz sand, but locally it contains } \\
\text { abundant fossil detritus and organic struc- } \\
\text { tures, including casts, molds, and borings of } \\
\text { mollusks and tests of Foraminifera and Bryozoa } 1 / \\
\text { Thickness 150-200 feet }\end{array}$ & Do. \\
\hline & PERIOD OF EROSION & \\
\hline $\begin{array}{l}\text { Ocala } \\
\text { Limestone } \\
\text { (Eocene) }\end{array}$ & $\begin{array}{l}\text { The Ocala is a pure, massive, marine, white to } \\
\text { tan, granular limestone, which is locally a } \\
\text { porous, friable, coquinalike mass of Foramini- } \\
\text { fera and mollusks in a chalky or pasty carbo- } \\
\text { nate matrix. } \\
\text { Thickness } 150-250 \text { feet } 1 /\end{array}$ & Do. \\
\hline
\end{tabular}


Table 1.--Hydrogeologic units--Continued

\begin{tabular}{|c|c|c|}
\hline $\begin{array}{c}\text { Name of } \\
\text { unit }\end{array}$ & Description & Remarks \\
\hline & PERIOD OF EROSION & \\
\hline $\begin{array}{l}\text { Avon Park } \\
\text { Limestone } \\
\text { (Eocene) }\end{array}$ & $\begin{array}{l}\text { (1) Cream to brown, highly fossiliferous, } \\
\text { miliolid-rich, marine, fragmental to pasty } \\
\text { limestone *** contains abundant specimens } \\
\text { of mollusks, Foraminifera, and corals. In } \\
\text { its porosity and fauna, it resembles a reef } \\
\text { and grades laterally and vertically through } \\
\text { a tan to brown, dense, brittle, thin litho- } \\
\text { graphic limestone; a 4- to 6-inch "fucoid- } \\
\text { Cerithium" fragmental dolomite; an irregular } \\
\text { lense of lignite and a Foraminifera-filled } \\
\text { dolomite-clay into the other rock types * *. } \\
\text { (2) Cream to brown, pasty and fragmental, peat- } \\
\text { flecked and seamed, very fossiliferous, marine } \\
\text { limestone. (3) Tan to brown, thin-bedded and } \\
\text { laminated, very finely crystalline marine dolo- } \\
\text { mite. * * The dolomite is composed of } \\
\text { euhedral, silt-sized, crystals of dolomite in- } \\
\text { terbedded with layers of lignite and carbona- } \\
\text { ceous plant remains * * } \text {. }\end{array}$ & $\begin{array}{l}\text { Modified from } \\
\text { Vernon, 1951, } \\
\text { p. } 96 .\end{array}$ \\
\hline
\end{tabular}

1/ Formation thickness from isopach maps compiled by Peter MacGill, in the files of the Florida Bureau of Geology. 


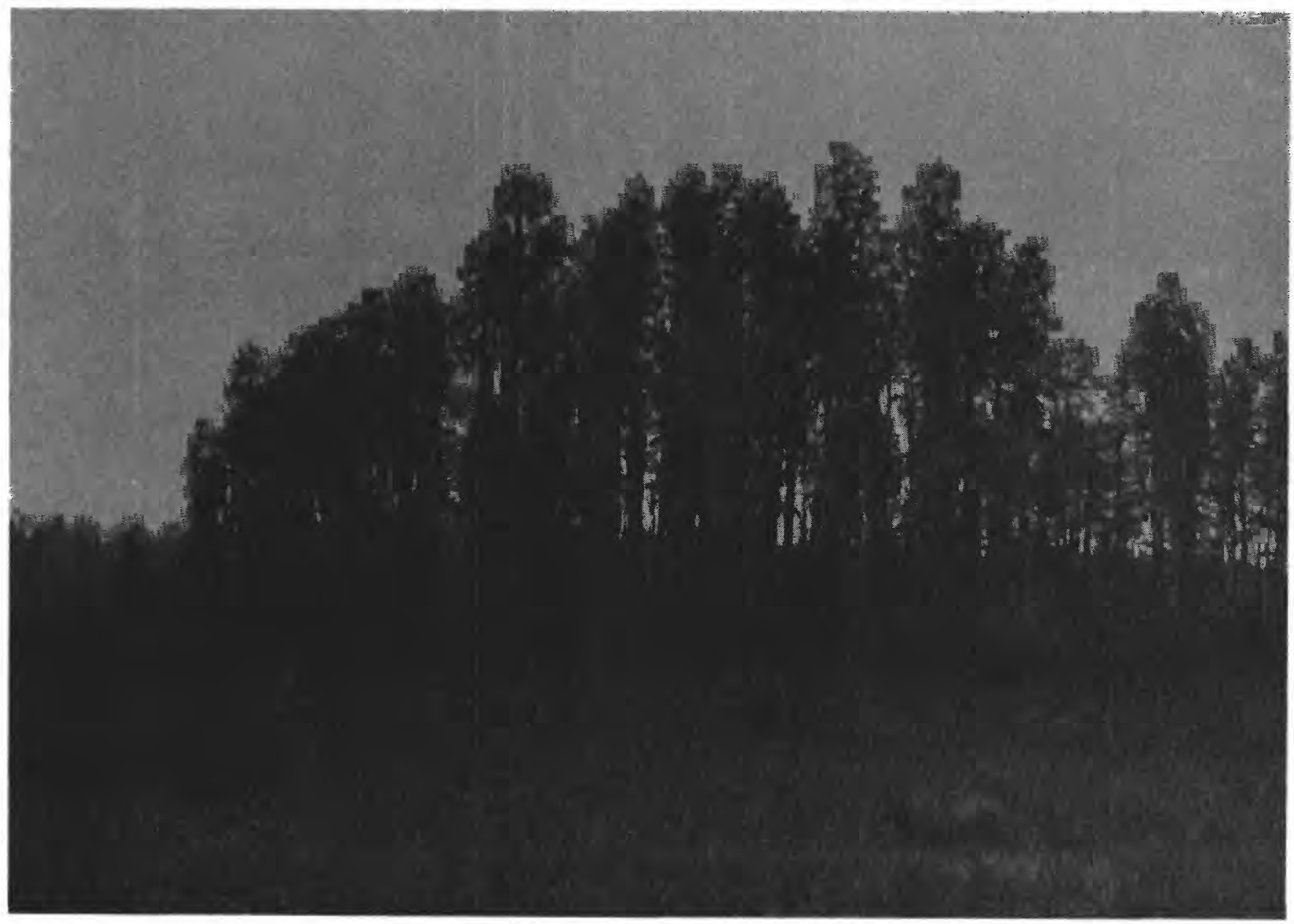

Figure 2.--Cypress head, typical of many on the Gulf Coastal Lowlands north of Tampa. 
As a depression develops, it becomes a sump for local runoff, and cypress and other phreatophytes thrive in the deep soil and alternating wet and dry conditions. As the depression continues to deepen and intercepts the water table, trees in the center are drowned. This results in a cypress-rimmed lake, a mature stage of sink development (Bishop, 1967).

\section{MECHANISM OF SINKHOLE COLLAPSE}

The chemical solution of limestone by percolating ground water takes place over long periods of time and is the fundamental cause of all sinkhole development. However, the natural process of solution, and resultant subsidence or collapse of the land surface, may be accelerated by works of man. Decline in ground-water levels caused by pumping results in loss of support to the bedrock and overburden. Sand and clay, whose specific gravity is about 2.5, weigh 40 percent less when immersed in water. Where clay forms a bridge over a solution cavity in the limestone, a decline in water level, with consequent withdrawal of 40 percent of the support of the dewatered sediments, might be sufficient to trigger collapse. Where pumpage has dewatered the aquifer, recharge is induced, ground-water flow is concentrated, and subsurface erosion and solution are accelerated. Loading of the land surface by construction or by ponding of water in reservoirs contributes to subsidence or collapse by weight alone or by concentration of water that percolates downward and causes subsurface erosion or solution. Collapses resulting from these effects have been termed "induced sinkholes" (Newton, 1976) as opposed to natural collapses or subsidence.

Surface expression of sinkholes and the lakes and cypress domes that they create is generally circular because of the nature of subsidence of the mantle of unconsolidated sand and the presence of the residual clay. Solution cavities developing in the top of the limestone are bridged by the residual clay layer until its bearing strength is exceeded. At this point, the clay collapses and overlying unconsolidated sand moves downward until the cavity is filled. Movement of incohesive sand may form a funnel-shaped depression. Vertical pipes are more common, however, because even clean, well-sorted sand has some degree of cohesion, particularly when wet. Dimensions of the cone or pipe are determined by the size of the void and the thickness and cohesiveness of the sand. Sinkholes commonly form abruptly to the funnel-shape stage, then more slowly by sloughing of the steep sides to the low-angle slope that is typical of depressions throughout the study area.

The distribution of sinkholes is controlled by the location of the underlying solution cavities. Solution of the limestone is enhanced where groundwater flow is concentrated. The most common features that control ground-water flow in Florida are bedding planes and erosion surfaces and vertical or nearvertical joints that commonly occur in intersecting sets. Sinkholes, cypress heads, and sinkhole lakes do not occur at random, but are commonly alined along the trace of underlying joint patterns.

Throughout the study area abrupt collapse of sinkholes is more common than gradual subsidence. Figure 3 illustrates the sequence of events in development of a sinkhole under the geohydrologic conditions in the Tampa area. The geology and hydrology of figure 3 are generalized from the 1 og of a test well drilled about 200 feet from the sinkhole (Sinclair, 1974, site 29, p. 22, 58). 
Solution cavities develop near the top of the limestone until the roof of the cavity is no longer able to support itself and collapses (fig. 3a). The dense plastic clay overlying the limestone may bridge the cavity for a considerable time by virtue of its cohesive strength, but, eventually, the clay will also collapse by spalling of material from the cavity roof (fig. 3b). The cavity will then move rapidly upward to the land surface as the noncohesive-sand roof also spalls and falls into it, perhaps accelerated by water percolating downward from the surficial aquifer (fig. 3c).

The photograph in figure $3 c$ was taken in 1971, shortly after the sinkhole appeared just south of the Section 21 well field. The photograph in figure $3 d$ was taken in 1981. In 10 years, the only additional movement has been surface erosion of peripheral material into the hole. Where the clay layer is sufficiently thick to completely fill the void in the limestone, ground-water flow may be diverted, retarding further solution at the site. Where the clay is thin, it is more likely that downward movement of water from the surficial aquifer will be enhanced to some extent by disruption of the clay layer and by increased surface drainage to the site as continued expansion of the land-surface depression collects more runoff.

Thickness and cohesiveness of overburden control, to a large degree, the shape and size of collapse areas at land surface. A thick section of dense cohesive clay may have sufficient bearing strength to bridge a bedrock cavity of considerable size. When the clay finally fails, a relatively large sinkhole will probably form abruptly. Upward coning of incohesive sand will create a relatively large diameter collapse in proportion to the thickness of the sand.

When water levels are lowered, the support by the water of clay and bedrock cavities is reduced. As a result, sinkholes may form over even small cavities. This is apparently what has occurred in the vicinity of Section 21 well field. Overburden in the area ranges from 20 to 100 feet thick and averages about 45 feet. The dense clay component, although discontinuous, averages 4 feet thick throughout the area (Sinclair, 1974). None of the induced sinkholes that occurred in recent years were more than 5 feet deep or more than 15 feet in diameter when the collapse first occurred. Eventually they expanded by slumping and erosion of the walls to the low angle typical of unconsolidated sand. The sinkhole shown in figure 4, for example, developed in the shore of Simmons Lake, within the Section 21 well field, in June 1971. The steep slope of the recent collapse, more than 1 foot per foot, is in sharp contrast to the slope of the lake basin, which is less than 1 foot per 20 feet. The sinkhole depressions occupied by Simmons Lake have become more extensive and shallow, throughout the centuries, as erosion has moved surface material from the expanding perimeter of the depression toward the relatively inactive centers of subsidence.

\section{EFFECTS OF PUMPAGE ON LIMESTONE SOLUTION}

Solution of carbonate aquifers by ground water is increased by pumping to the extent that pumping concentrates and accelerates movement of water through the aquifer and induces increased downward percolation of water from the overlying surficial aquifer. Chemical analyses of water from the Floridan aquifer 


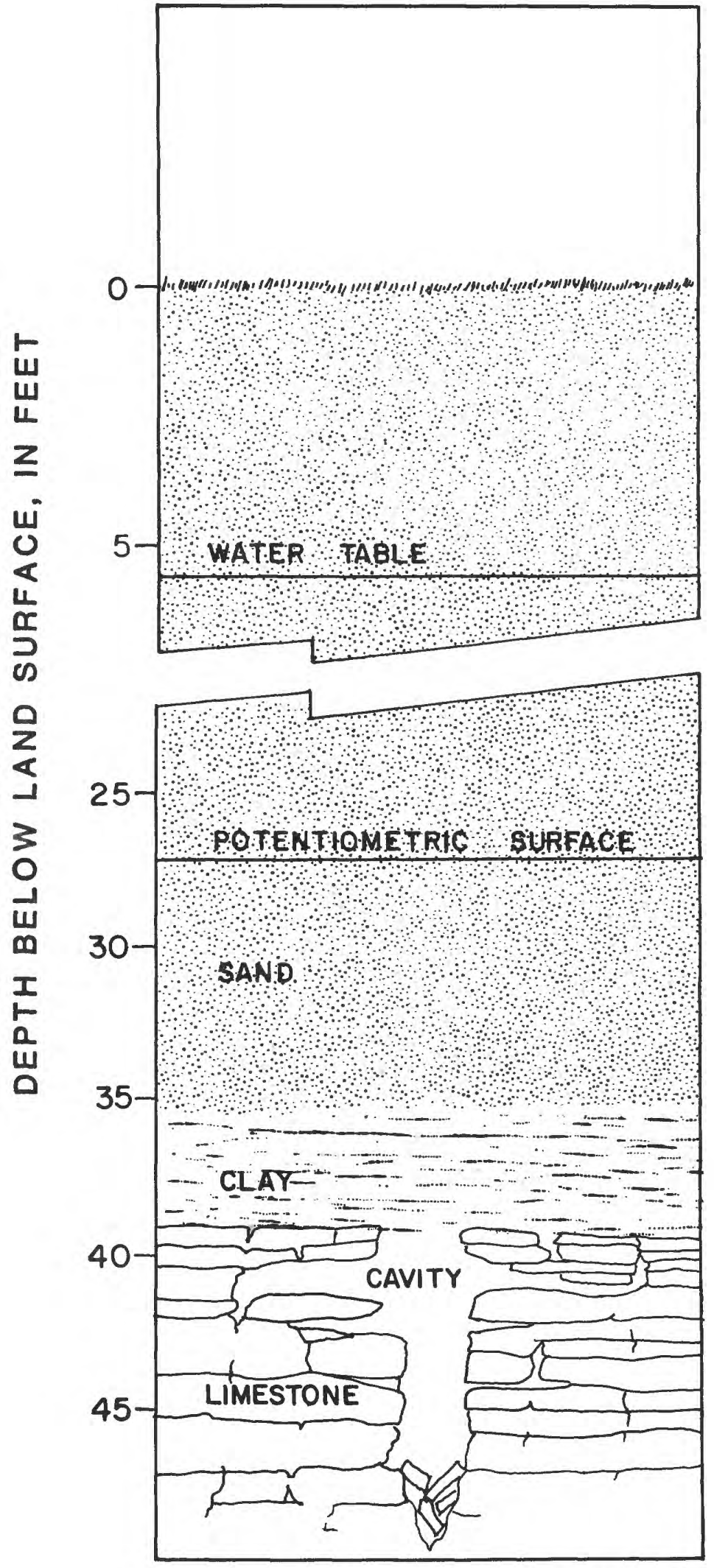

a. Cavity dissolved in limestone by percolating ground water. Time: Centuries.
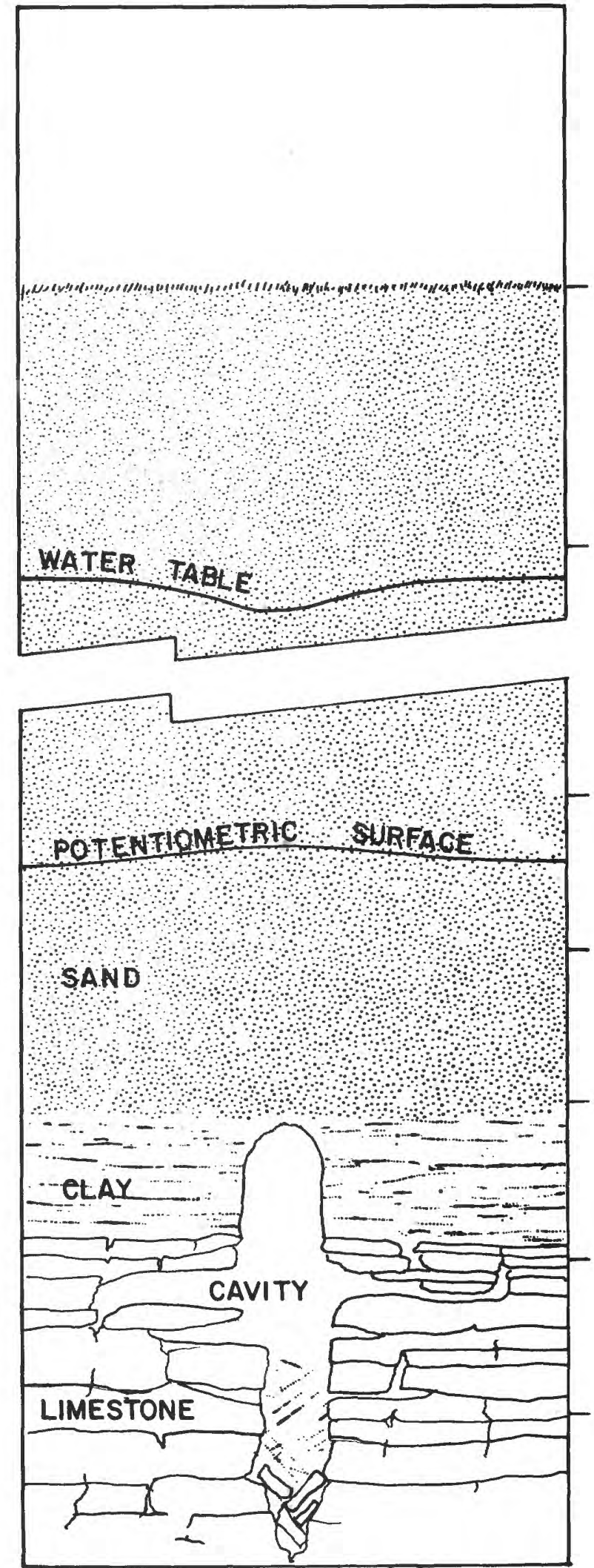

b. Collapse of overlying clay into cavity by spalling. Time: Months - years.

Figure 3.--Mechanism of 

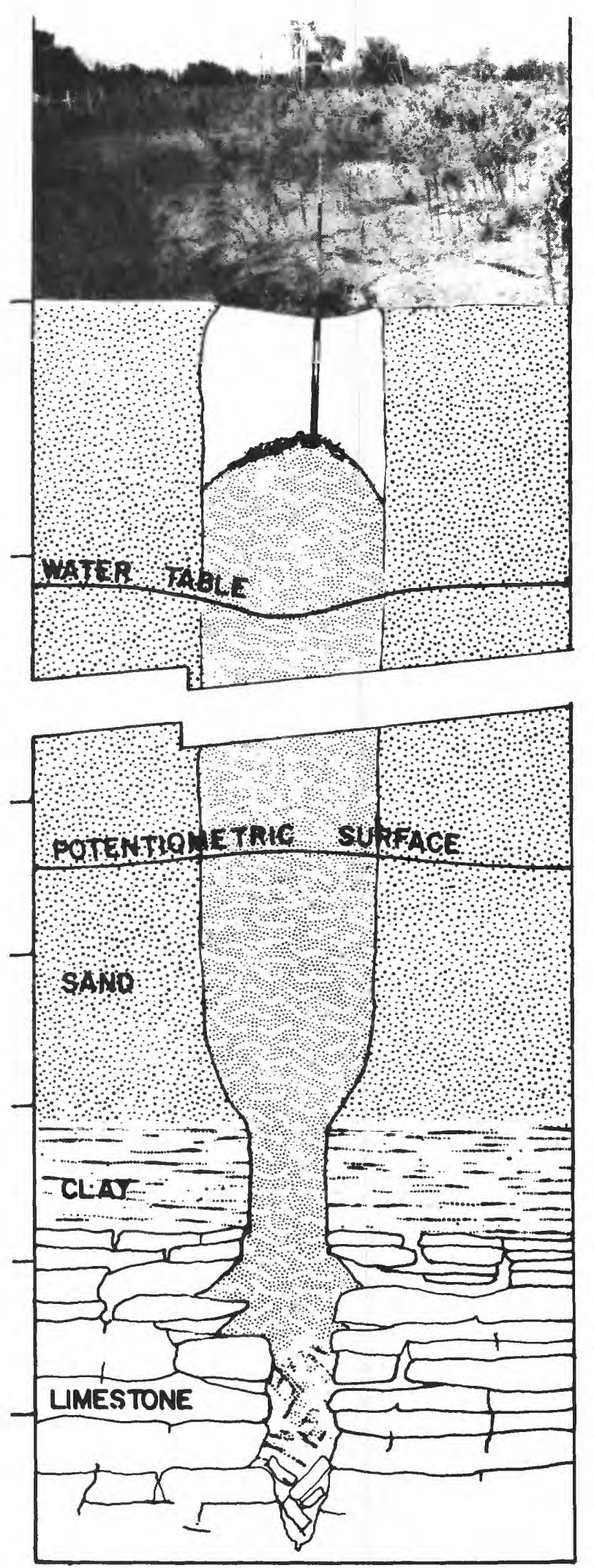

c. Piping of cohesionless sand into cavity.

Time: Hours - days.
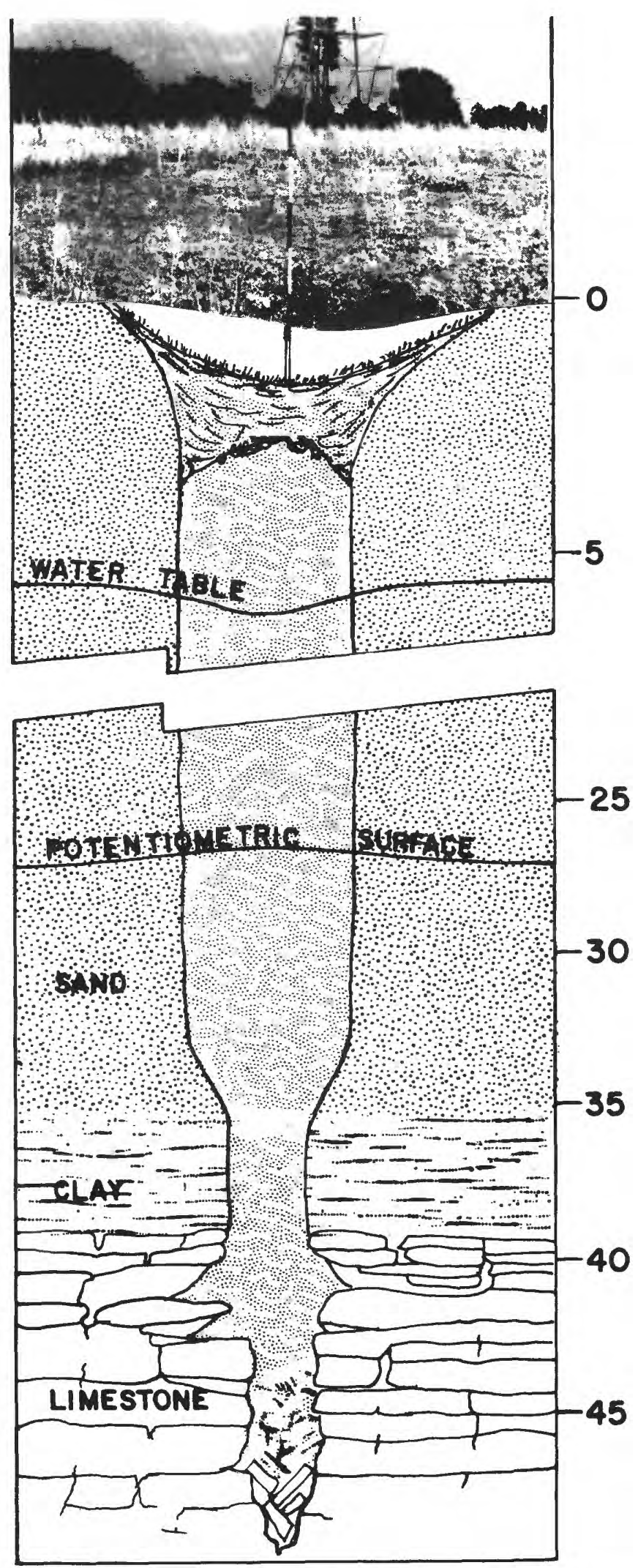

d. Modification of sinkhole by surface erosion.

Time: Ten years.

sinkhole collapse. 


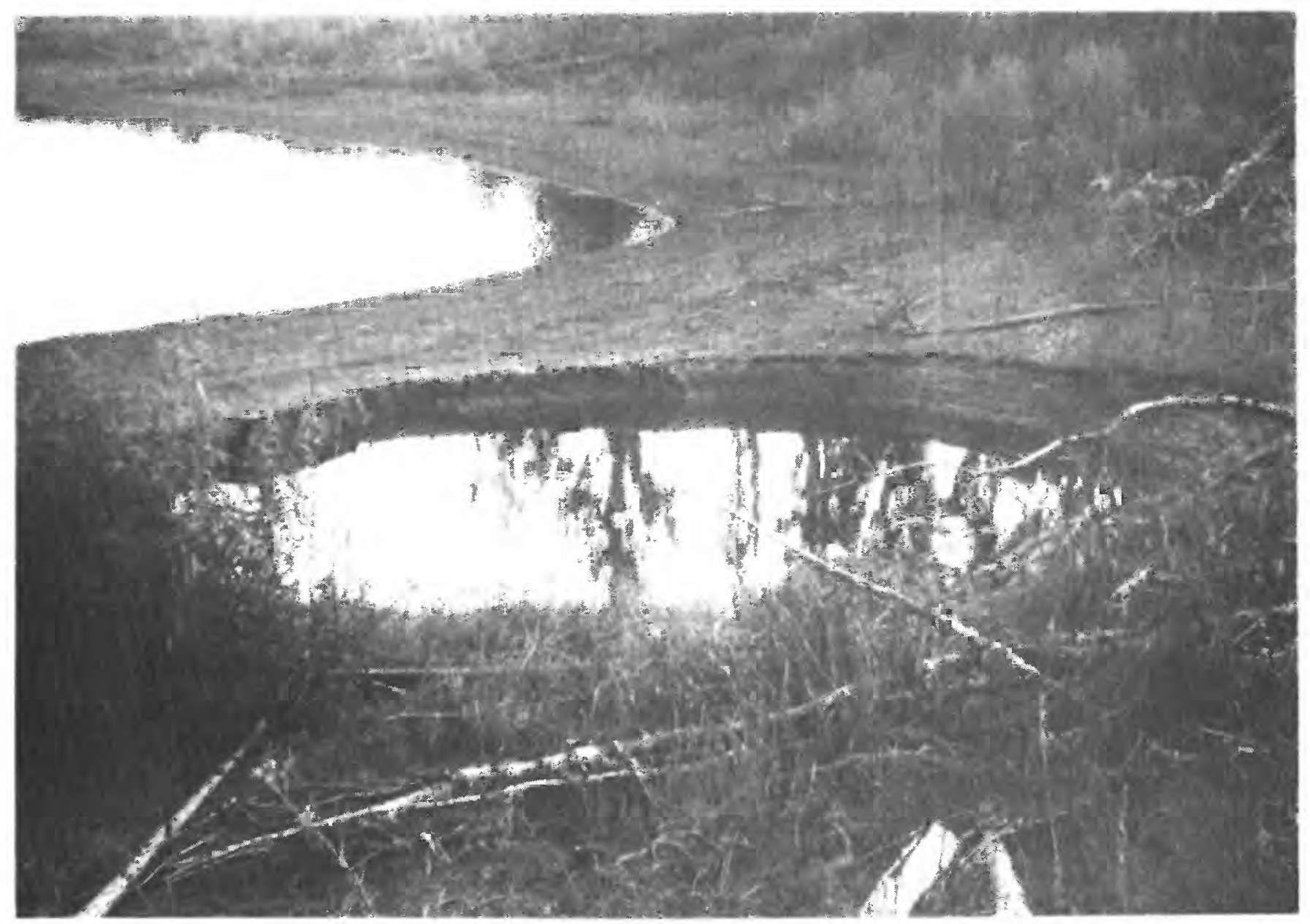

Figure 4.--Sinkhole that developed in the shore of Simmons Lake, Section 21 well field, in the summer of 1971. 
have been made and tabulated since the earliest wells were drilled in the area (Menke and others, 1964; Leggette, Brashears, and Graham, 1966). The data show that total calcium, magnesium, and carbonate, the principal constituents of carbonate rocks, average about $200 \mathrm{mg} / \mathrm{L}$ (milligrams per liter) in water from the pumped zone of the aquifer. For every gallon of water pumped, 0.00167 pounds of limestone and dolomite that are in solution are removed from the aquifer. Records from the Section 21 well field show that pumpage has totaled 74 billion gallons from the time production began in 1963 through 1978. This represents 62,000 tons of limestone and dolomite (calcium, magnesium, and carbonate) that have beȩn pumped from the aquifer. The nominal weight of limestone is about $160 \mathrm{lb} / \mathrm{ft}^{3}$, or a total of $770,000 \mathrm{ft}^{3}$ of 1imestone that was in solution has been removed through 1978 .

Total pumpage from the four well fields in the study area in 1978 averaged $62 \mathrm{Mgal} / \mathrm{d}$ or 22.6 billion gallons for the year. Applying the above calculations, about 19,000 tons or $240,000 \mathrm{ft}^{3}$ of limestone in solution were removed from the aquifer.

It was demonstrated by Bogli (in Sweeting, 1973, fig. 7) that most limestone solution takes place in the first second of contact with agressive water. The most significant effect of pumping on solution of the Floridan aquifer is probably due to induced recharge and occurs at the limestone surface throughout the area affected by pumping. Recharge is probably concentrated at existing sinkholes. These sinkholes may be expected to continue to grow, but at a rate measured in geologic time.

At the Section 21 well field, the area of pumpage-induced recharge extends about 1 mile in $7^{a 11}$ directions from the field and affects a surface area of about $8.76 \times 10^{7 t^{2}}$. The $770,000 \mathrm{ft}^{3}$ of limestone dissolyed due to pumping from this area for 15 years (1963-78) amounts to $0.009 \mathrm{ft}^{3}$ for each square foot of the induced recharge area, a rather negligible volume when considered in terms of the area affected. At the current rate of pumpage, the limestone surface would be lowered 1 foot throughout the area of influence in about 1,700 years. The natural rate of denudation of Florida limestone was estimated by Sellards (1908, p. 48) to be about 1 foot in 5,000 or 6,000 years.

\section{SINKHOLE COLLAPSE INDUCED BY PUMPAGE}

Natural sinkhole development is endemic to the study area and will continue as part of the natural geologic evolution of the landscape. Activities of man, however, tend to accelerate the process.

The effects of pumping on sinkhole development at the Section 21 well field are cited here because they were well documented and serve as a model of the type of sinkhole development that stress may induce in the hydrogeologic terrane typical of the study area.

Pumping at the Section 21 well field began in February 1963 at a rate of about $5 \mathrm{Mgal} / \mathrm{d}$ and continued at that rate until March 1964 when it was increased to $11 \mathrm{Mgal} / \mathrm{d}$, and increased again in April 1964 to $14 \mathrm{Mgal} / \mathrm{d}$. Monthly pumpage is shown in figure 5 along with water-level fluctuations in wells finished in 


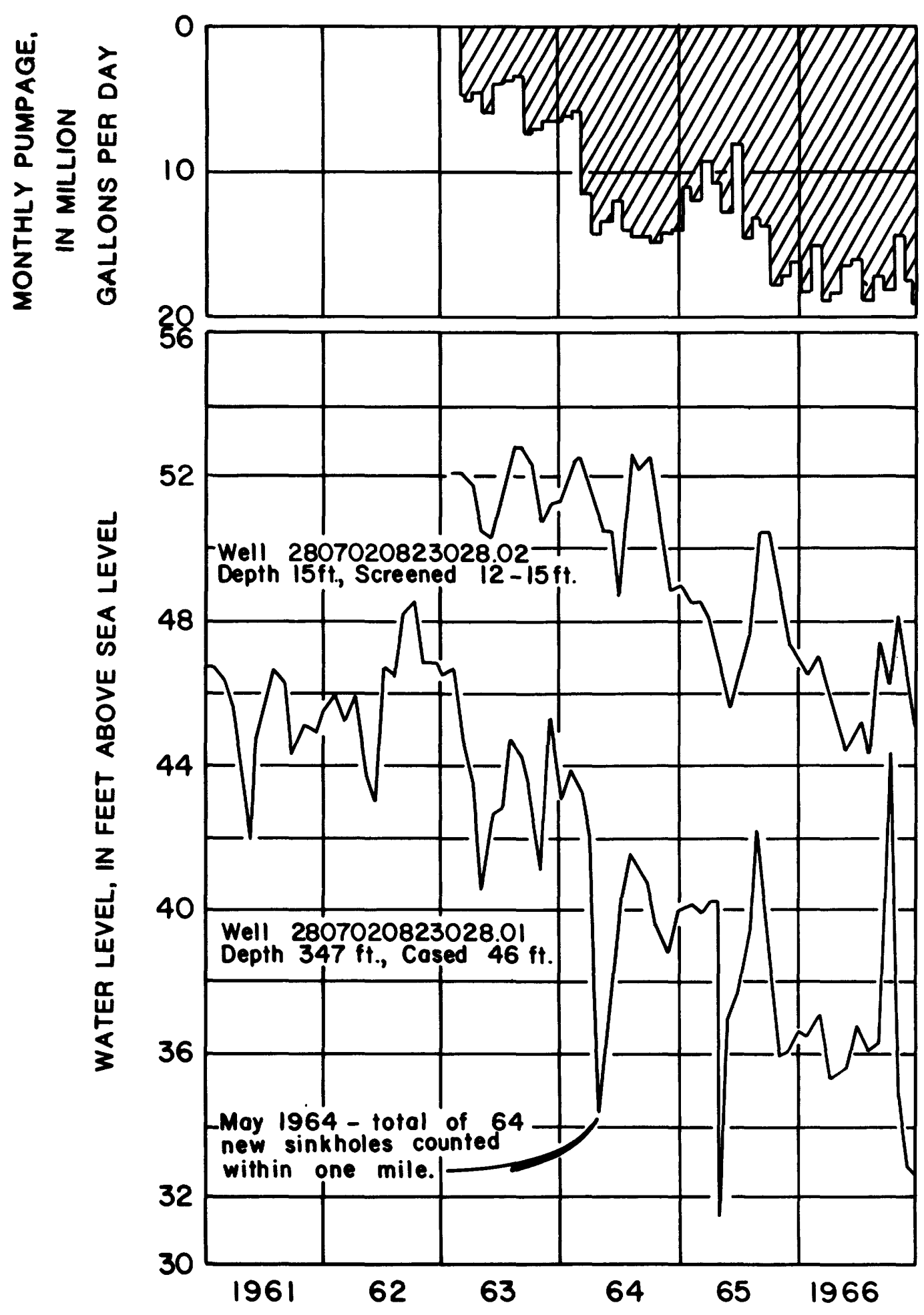

Figure 5.--Pumpage at Section 21 well field and water-level fluctuations in shallow and deep observation wells (modified from Stewart, 1968). 
the Floridan and surficial aquifers. The two wells are located near the center of the well field (fig. 6). Seasonal declines shown by the graph for the Floridan aquifer we11 were increased due to pumping in 1963 and, more dramatica11y, in 1964. Seasonal declines in the surficial aquifer well are also much greater due to increased leakage to the Floridan aquifer caused by the sharply increased difference in water levels in the two aquifers.

By May 1964, well-field personnel and neighboring landowners reported 64 new sinkholes within a 1-mile radius of the well field (Frank Crum, personal commun., 1979). Reference points were placed in the bottoms of the sinkholes and they were surveyed periodically for 3 years. During this period, only two of the sinkholes subsided further, 1 foot and 0.8 foot. Although pumpage has continued, even increased, and sinkholes have appeared occasionally, the rash of sinkhole collapse was short-lived and was not repeated. Apparently the sudden decline in artesian pressure, the induced decline in the water table, and increased downward leakage combined to trigger the collapse of cavities whose size had already become critical with respect to the bearing strength of the overlying clay.

Most sinkholes that occurred near the Section 21 well field and that were reported are shown in figure 6 . The sinkholes occurred in apparently random clusters, although those east of well $21-10$ and those south of it are roughly alined along traces that are nearly at right angles, possibly the effect of joint control on cavity development. Most sinkholes developed in the vicinity of well 21-10. This well was pumping at a rate of $4,200 \mathrm{gal} / \mathrm{min}$, nearly twice the average rate of pumping of the other five wells in the field. The pumping rate of well 21-10 was subsequently reduced to about half.

Test drilling has shown that the clay layer separating the surficial and Floridan aquifers is thin or absent southeast of the well field, and a depression in the water table suggests good hydraulic connection between the surficial and Floridan aquifers in the area that includes many of the sinkhole clusters (Sinclair, 1974, fig. 1).

Sinkholes occurred in conjunction with the development of the Cosme well field in 1930 and E1dridge-Wilde well field in 1954, but those areas were sparsely settled at the time and little notice was made. What records do exist, along with recent field examination, suggest that the sinkholes developed in a manner similar to those near Section 21. The South Pasco well field began pumping in 1973 and more than 30 small sinkholes were identified in the following year (R. Moresi, Southwest Florida Water Management District, written commun., 1976). A11 were in cleared land and pasture north of the well field. None were found in the cypress swamps and pine-palmetto that comprise the other three quadrants surrounding the well field.

Sinkhole collapse due to ground-water pumping was documented in an area about 4 miles south of the Section 21 well field (site 1, fig. 1). A residential lot had many small sinkholes, one of which threatened extensive damage to a home. Suspicion centered on a nearby well as the cause. A court-ordered test, designed by Robert Ogilby (written commun., 1979), demonstrated a dramatic cause and effect relationship. The largest incipient sinkhole was bridged with a long timber. A machinist's strain gage, anchored to the timber, was placed in contact with a steel rod anchored in the center of the subsided area. The strain gage was read daily for 3 months and showed only nominal fluctuations. 


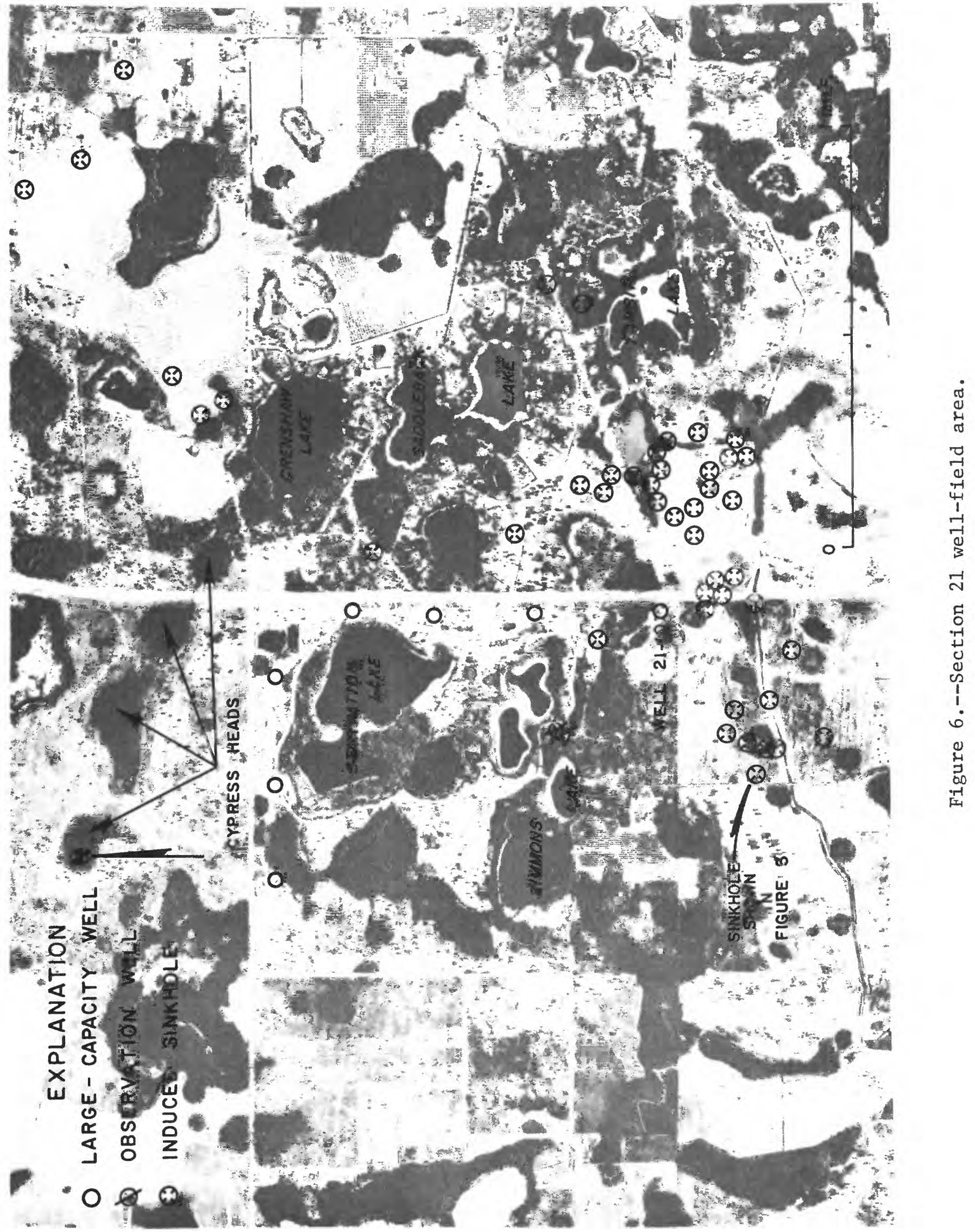


During this period, the suspect well was not pumped, although other wells in the area, some of them closer to the sinkhole than the suspect well, were in use. When the suspect well was pumped at a rate of about $30 \mathrm{gal} / \mathrm{min}$, subsidence was immediate, though slight. After 3.25 hours of pumping, subsidence totaled 0.161 inch. Three subsequent tests yielded similar results. Although the rate of subsidence varied in the four tests from 0.0182 to 0.0495 inch per hour, response to pumping was immediate in every test. The response to pumping suggests that the suspect well draws water from a solution cavity that is open to the unconsolidated sand and clay beneath the site and that subsidence was due to the removal of sand and clay particles by ground water moving at relatively high velocity toward the pumping well.

Another case where cause and effect were clearly demonstrated was reported by Hillsborough County hydrologists Hall and Metcalfe (1981). In January 1977, temperatures dropped as low as $25^{\circ} \mathrm{F}$ in the vicinity of Dover, about 20 miles east of the study area (site 2, fig. 1), and strawberry farmers protected their crops from freezing by irrigating with ground water. Because of the heavy pumping, water levels in the Floridan aquifer declined as much as 60 feet overnight. Hall and Metcalfe reported that 22 newly developed sinkholes were brought to their attention within the next few days. Although the Dover area is typical of Florida's covered karst, and sinkholes are not uncommon, the occurrence of 22 sinkholes within a matter of days is unique and obviously related to the sudden decline in ground-water levels.

\section{PRECURSORS OF SINKHOLE COLLAPSE}

Although the occurrence of sinkholes in the study area is generally abrupt, one or more common precursors may occur prior to collapse:

1. Slumping or sagging.--Canting of fence posts or other objects from the vertical and doors and windows that fail to open or close properly may be early warnings of subsidence.

2. Structural failure.--Cracks along mortar joints in walls and in pavements, however small, may be indications of subsidence.

3. Ponding.--The ponding of rainfall may serve as a first indication of actual land subsidence.

4. Vegetative stress.--One of the earliest effects at an incipient sinkhole is lowering of the water table through percolation to the underlying Floridan aquifer. The lowered water table may result in visible stress to a small area of vegetation.

5. Turbidity in well water.--Water sometimes becomes turbid during the early stages of development of a nearby sinkhole.

\section{CONCLUSIONS}

Recent occurrence of sinkholes has been related, in part, to abrupt waterlevel declines caused by pumping. Collapse and subsidence is caused, not by recent solution of the limestone, but by downward migration of the unconsolidated surficial material that overlies and fills existing cavities in the rock. 
Continued sinkhole collapse is inevitable in the study area. Changes in the hydrologic regimen will continue to contribute to sinkhole development, particularly as a result of drawdown of water levels in response to seasonal demands for water. Collapse of the land surface, rather than subsidence, is to be expected because of the structural integrity of clay layers overlying openings in the limestone. The size of induced sinkholes will be sma11, principally because of the moderate thickness of unconsolidated surficial material. Future sinkholes probably will not be larger or more catastrophic than those induced to date.

Alinement of established sinkholes along presumed joint sets suggests that wells located along these lineations might have direct hydraulic connections with a zone of incipient sinkholes. The location of induced sinkholes near the Section 21 well field, however, does not appear to be entirely controlled by existing lineations because the sinkholes appear in clusters in the vicinity of the most heavily pumped well.

Solution of carbonate rocks, induced by pumpage, totaled about $240,000 \mathrm{ft}^{3}$ in 1978. Most solution took place at the limestone surface. The area of induced recharge, however, is so extensive that the effect of induced limestone solution on sinkhole development is negligible.

Although sinkhole collapse is commonly abrupt in the study area, local changes, such as vegetative stress, ponding of rainfall, misalinement of walls, cracks in masonry, and turbidity in well water, may be indicators of precollapse subsidence.

\section{REFERENCES}

Bishop, E. W., 1967, A tentative classification of lake shorelines in Florida lakes: Tallahassee, Florida Board of Conservation, Division of Water Resources, p. 53-62.

Carr, W. J., and Alverson, D. C., 1959, Stratigraphy of middle Tertiary rocks in part of west-central Florida: U.S. Geological Survey Bulletin 1092, $111 \mathrm{p}$.

Ha11, L. E., and Metcalfe, S. J., 1981, Sinkhole collapse due to groundwater pumpage for freeze protection irrigation near Dover, Florida, January, 1977, in Karst Hydrology, International Association of Hydrogeologists (in press).

Leggette, Brashears, and Graham, 1966, Summary report of ground-water investigations in northwestern Hillsborough County, Florida: Consultant report for city of St. Petersburg.

Menke, C. G., Meredith, E. W., and Wetterha11, W. S., 1964, Water-resources records of Hillsborough County, Florida: Florida Division of Geology Information Circular 44, 95 p.

Newton, J. G., 1976, Early detection and correction of sinkhole problems in Alabama, with a preliminary evaluation of remote sensing applications: Alabama Highway Research, HPR Report no. 76.

Sellards, E. H., 1908, The underground water supply of central Florida: Florida Geological Survey Bulletin 1, 103 p. 
Sinclair, W. C., 1974, Hydrogeologic characteristics of the surficial aquifer in northwest Hillsborough County, Florida: Florida Bureau of Geology Information Circular 86, 98 p.

Stewart, J. W., 1968, Hydrologic effects of pumping from the Floridan aquifer in northwest Hillsborough, northeast Pinellas, and southwest Pasco Counties, Florida: U.S. Geological Survey open-file report EL-68005.

Sweeting, M. M., 1973, Karst land forms: Columbia University Press, New York, $362 \mathrm{p}$.

Vernon, R. 0., 1951, Geology of Citrus and Levy Counties, Florida: Florida Geological Survey Bulletin 33, 256 p. 
